Bangladesh J. Plant Taxon. 21(2): 121-128, 2014 (December)

(C) 2014 Bangladesh Association of Plant Taxonomists

\title{
MORPHOMETRICS OF THE TRIBE MERREMIEAE AUSTIN (CONVOLVULACAE) FROM INDIA
}

\author{
S. A. Deshmukh and Vinod B. Shimpale ${ }^{1}$ \\ Department of Botany, The New College, Kolhapur- 416 012, (MS), India
}

Keywords: Convolvulaceae; Merremieae; Numerical Taxonomy; Principal component analysis.

\begin{abstract}
Sixteen species of the tribe Merremieae Austin (Convolvulaceae) from India were morphometrically analyzed with the help of Principal component analysis (PCA) and cluster analysis to explain the relationship between them. PCA showed that quantitative characters like corolla breadth, fruit breadth and length of paracot leaf play important role in bringing together all the species in the same tribe while the characters like leaf length, leaf breadth, petiole length, pedicel length, calyx length and calyx breadth play vital role in the delimitation of taxa within the tribe Merremieae. Cluster analysis and dendrogram revealed that, the genus Operculina S. Manso is segregated from Merremia Denns. ex Endlich.; genus Hewittia Wight. \& Arn. is very close to Merremia, probably originated from M. aegyptia (L.) Urban and M. dissecta (Jacq.) Hall. f. cluster and genus Xenostegia Austin \& Staples is isolated in the separate cluster.
\end{abstract}

\section{Introduction}

The Convolvulaceae is one of the largest families of angiosperms consist of 52 genera and 1650 species (Mabberley, 2008) and mainly distributed in the tropical and subtropical regions of the world. Some members of the family Convolvulaceae are medicinally as well as economically important (Austin, 1982; Chopra et al., 1995; Kamalutheen et al., 2009; Sahu and Gupta, 2014).

The tribe Merremieae Austin is a diverse tribe in the family Convolvulaceae. Due to many overlapping characters in the members of tribe Merremieae, their proper identification is confusing, which may be due to the lack of sound morphological characters to define it and increase in the number of published species in this tribe. The tribe possesses four genera, viz., Hewittia R. Wight \& Arnott, Merremia Dennst. ex Endl., Operculina Silva Manso and Xenostegia Austin \& Staples. The genus Hewittia is represented by a single species, Merremia by 70 species, Operculina by 15 species and Xenostegia by only two species in the world (Mabberley, 2008). The present study reveals that, in India the genus Hewittia is represented by a single species, while the genera Operculina and Xenostegia consist of two species each, and the genus Merremia is represented by 11 species.

Numerical taxonomy plays important role in segregation of taxa. Cluster analysis (CA) and Principal component analysis (PCA) techniques are commonly used in determining the phylogenetic relationships among different taxa. Applying various methods of numerical taxonomy many authors, e.g. Sneath and Sokal (1973), Chiapella (2000), Gomez-Campo et al. (2001), Sonibare et al. (2004), Henderson (2006), Soladoye et al. (2010), Rahman et al. (2013) and many others have interpreted interrelationship among different genera and families of flowering plants. According to Sonibare et al. (2004) cluster analysis provides a hierarchical classification of entities (taxa) based on the similarity matrix, while PCA is a second method used for reducing the dimensions of the original data which allows visual interpretation of the relationships.

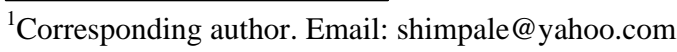


Using macromorphological data and seedling character variations the present study aims to delimit the following 16 species of the tribe Merremieae and to evaluate systematic relationships within the tribe.

\section{Materials and Methods}

Plant specimens:

Sixteen species of the tribe Merremieae are listed in Table 1. Freshly collected as well as herbarium specimens deposited in BSI, BAMU, PBL, SUK and herbarium of the The New College, Kolhapur were used in this study. Fresh specimens were collected from different localities of India during 2005 to 2011. Some morphological characters are based on herbarium specimens (Table 1). The species were identified and authenticated with the help of relevant literature (Hooker, 1885; Cooke, 1958; Austin and Staples, 1980; Johari, 1983; Gamble, 1986; Bhandari, 1995; Biju, 1997; Almeida and Almeida, 2001; Singh et al., 2001; Bhagat et al., 2009). All the specimens are deposited in the herbarium of The New College, Kolhapur (NCK), India.

Table 1. List of species of the tribe Merremieae along with voucher specimens.

\begin{tabular}{|c|c|c|}
\hline No. & Species & Specimens examined \\
\hline 1 & Hewittia malabarica (L.) Suresh & $\begin{array}{l}\text { Maharashtra: Ratnagiri, Bhatia beach, 2.11.2011, Shimpale } \\
9835 \text { (NCK) }\end{array}$ \\
\hline 2 & Merremia aegyptia (L.) Urban & Maharashtra: Sangali, Miraj, 8.11.2006, Shimpale 3998 (NCK) \\
\hline 3 & M. dissecta (Jacq.) Hall. f. & $\begin{array}{l}\text { Maharashtra: Osmanabad, Kasabe Tadawale, 25.1.2009, } \\
\text { Shimpale } 4098 \text { (NCK) }\end{array}$ \\
\hline 4 & M. gangetica (L.) Cuford. & $\begin{array}{l}\text { Maharashtra: Kolhapur, Rankala, 12.12.2012, Shimpale } 5620 \\
\text { (NCK) }\end{array}$ \\
\hline 5 & M. hederacea (Burm. f.) Hall. f. & $\begin{array}{l}\text { Maharashtra: Pune, Baramati, 12.11.2008, Shimpale } 2209 \\
\text { (NCK) }\end{array}$ \\
\hline 6 & M. peltata (L.) Merr. & Great Nicobar Island: Dwivedi 17024 without date (PBL) \\
\hline 7 & M. quinquefolia (L.) Hall. f. & $\begin{array}{l}\text { Maharashtra: Kolhapur, Sarnobatwadi, 9.2.2010, Shimpale } 5629 \\
\text { (NCK); Karnataka Belgaum district, Nipani, 23.3.2010, VBS } 63 \\
\text { (SUK) }\end{array}$ \\
\hline 8 & M. rajsthanensis Bhandari & $\begin{array}{l}\text { Rajsthan: Jodhpur, Sardarsamand, 29.8.1975, Bhandari } 1976 \\
\text { (CAL) }\end{array}$ \\
\hline 9 & M. rhyncorhiza (Dalz.) Hall. f. & $\begin{array}{l}\text { Karnataka: Belgaum, Kankumbi, 17.8.2008, Shimpale } 3342 \\
\text { (NCK) }\end{array}$ \\
\hline 10 & M. tuberosa (L.) Rendle & $\begin{array}{l}\text { Maharashtra: Kolhapur, Tarabai Park, 29.12.2009, Shimpale } \\
2629 \text { (NCK) }\end{array}$ \\
\hline 11 & M. umbellata (L.) Hall. f. & Maharashtra: Kolhapur, Dajipur, 22.3.2006, Shimpale 269 (NCK) \\
\hline 12 & M. vitifolia (Burm.f.) Hall. f. & Maharashtra: Kolhapur, Dajipur, 22.3.2006 Shimpale 276 (NCK) \\
\hline 13 & $\begin{array}{l}\text { Operculina tansaensis Sant. \& } \\
\text { Patel }\end{array}$ & $\begin{array}{l}\text { Maharashtra: Thane, Thansa lake, 28.11.2010, Shimpale } 3229 \\
\text { (NCK) }\end{array}$ \\
\hline 14 & O. turpethum (L.) S. Manso & Maharashtra: Ratnagiri, Dapoli, 16.1.2008, Shimpale 998 (NCK) \\
\hline 15 & $\begin{array}{l}\text { Xenostegia filiformis (Thunb.) } \\
\text { Almeida }\end{array}$ & Karnataka: Khanapur, 2.1.2001, Shimpale 794 (NCK) \\
\hline 16 & X. tridentata (L.) Hall. f. & $\begin{array}{l}\text { Maharashtra: Sindhudurg, Malvan, 12.11.2009, Shimpale } 754 \\
\text { (NCK); Nanded District, Dharmabad, 12.12.1993 Madhukar } \\
6716 \text { (BAMU) }\end{array}$ \\
\hline
\end{tabular}




\section{Morphometric studies:}

Morphometric studies were carried out on freshly collected as well as herbarium specimens that are deposited in BSI, BAMU, PBL, SUK and The New College, Kolhapur (NCK). Measurements were taken for 19 selected quantitative characters e.g. leaf length, leaf breadth, petiole length, pedicel length, calyx length, calyx breadth, corolla length, corolla breadth, stamen length, filament length, anther length, ovary length, style length, fruit length, fruit breadth, seed length, seed breadth, apical notch length, paracot length, and recorded on record sheets using as many as numbers of specimens were available for each taxonomic operational unit (OTU). The mean and standard deviation values for all the 19 quantitative characters were calculated and processed for PCA and CA (Kovach, 1999) by keeping data standardized at similarity matrix and tolerance of Eigen analysis set at 1E-010.

\section{Results and Discussion}

Nineteen parameters of 16 species of the tribe Merremieae from India were examined using numerical methods. The morphological features employed for delimitation of the 16 species with their means and standard deviations are shown in Table 2.

Similarity matrix based on correlation of Merremieae species (Table 3) shows that close resemblance of species could be observed when certain characters are employed. It is observed that, there is significant correlation between leaf length and corolla breadth, leaf length and corolla length, leaf breadth and petiole length, leaf breadth and calyx length, petiole length and calyx length, petiole length and corolla breadth, pedicel length and paracot length, calyx length and calyx breadth, calyx breadth and fruit breadth, corolla length and corolla breadth, corolla length and style length, corolla breadth and style length, stamen length and paracot length, filament length and paracot length, style length and fruit breadth, style length and seed length, fruit length and seed length, fruit length and fruit breadth.

Cluster analysis shows that Xenostegia tridentata distinctly differs from Hewittia malabarica and Merremia aegyptia while both the species of the genus Xenostegia, distinctly differs from $M$. dissecta, M. hederacea, M. peltata, M. quenquifolia, M. rajsthanensis, M. rhyncorhiza, M. tuberosa, M. vitifolia, Operculina tansaensis and O. turpethum (Table 4). Merremia tuberosa distinctly differs with $H$. malabarica, M. aegyptia, M. gangetica, M. quenquifolia, $M$. rajsthanensis and $M$. umbellata. It was also determined that Operculina turpethum is closely related with the $O$. tansaensis, $M$. vitifolia, $M$. rhyncorhiza, $M$. dissecta and $M$. aegyptia, while $M$. vitifolia closely relate with $M$. umbellata, $M$. rajsthanensis, M. quenquifolia, $M$. dissecta and $H$. malabarica. The relationships among the species of the tribe Merremieae is shown in Figure 1.

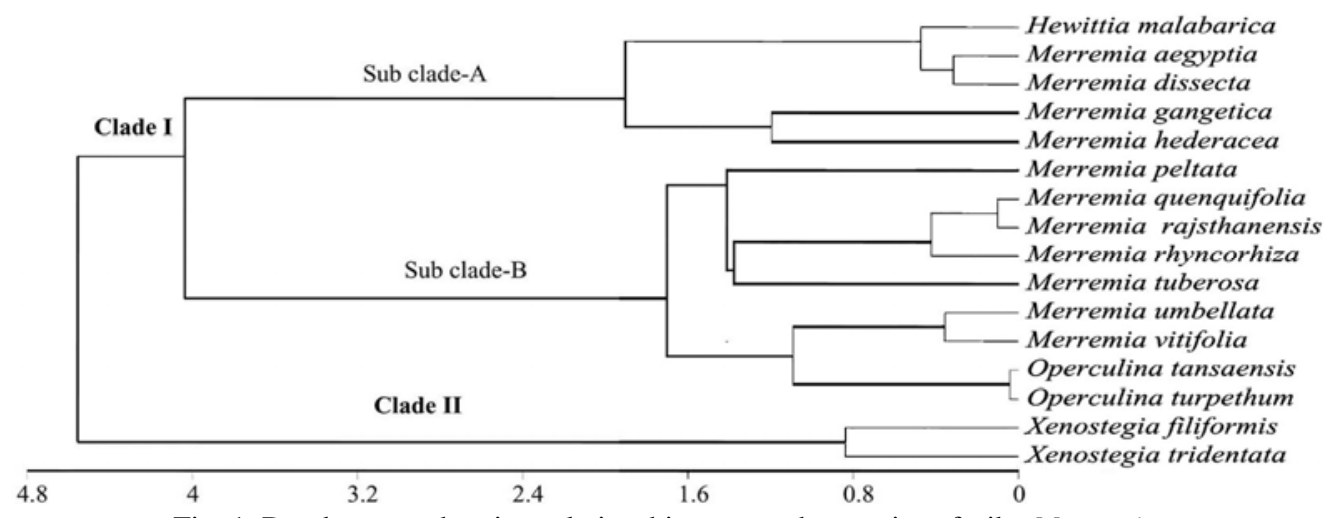

Fig. 1. Dendrogram showing relationship among the species of tribe Merremieae 


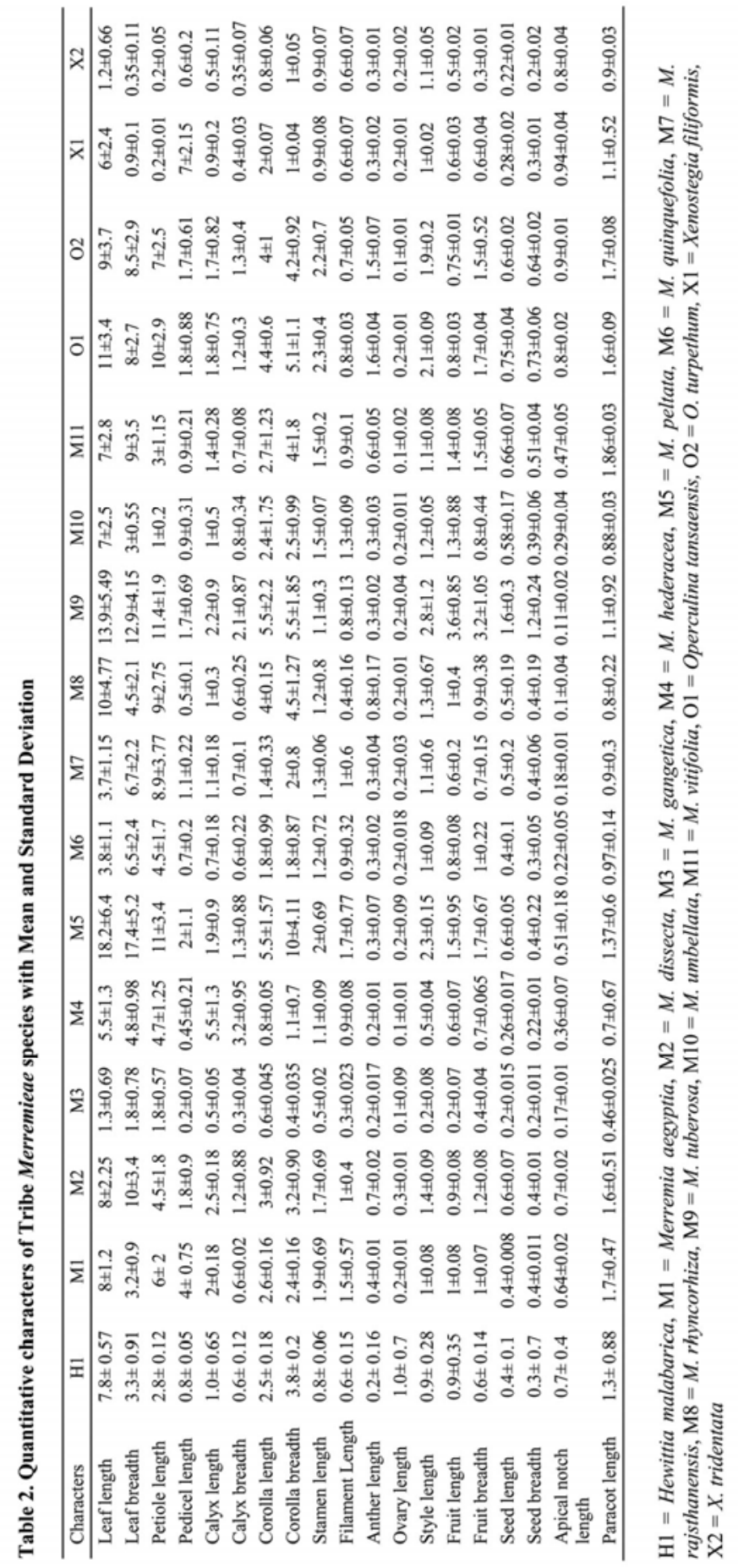




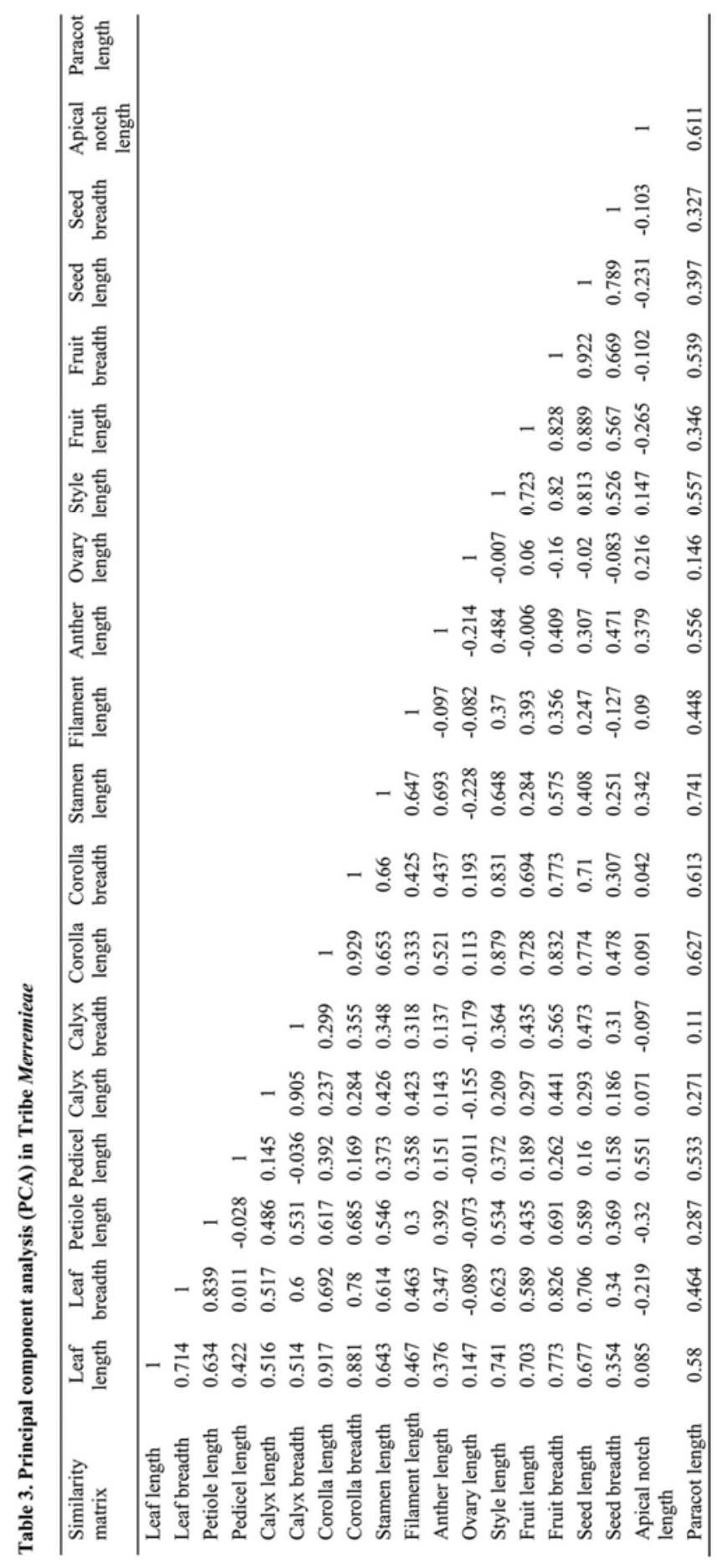




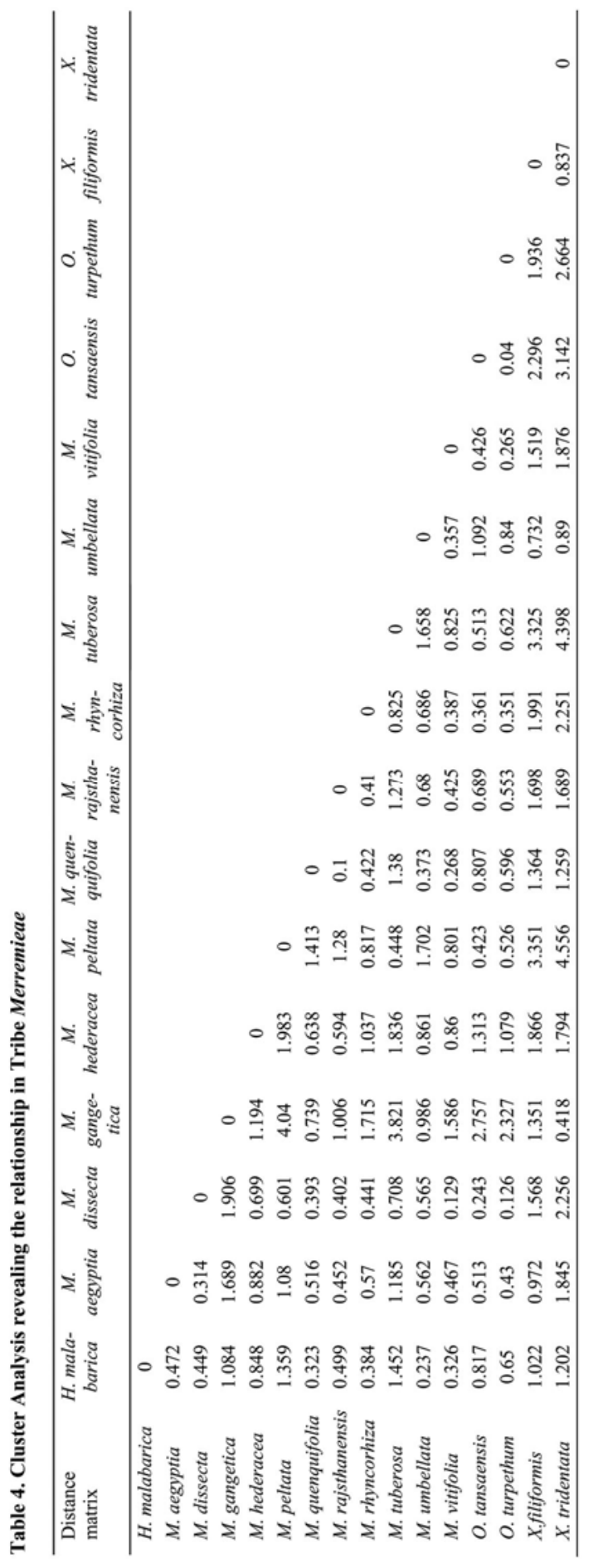


UPGMA dendrogram based on cluster analysis, mean character difference and constrained clustering strategy reveals that, greater affinity exists in between Operculina tansaensis and $O$. turpethum (Fig. 1). It is also pointed out that, in dendrogram, 16 species clearly forms distinct two clades i.e. I and II. Clade I is divided into subclade A and subclade B. Subclade A comprises Hewittia malabarica, M. aegyptia, M. dissecta, M. gangetica and $M$. hederacea, while subclade B comprises $M$. peltata, $M$. quenquifolia, M. rajsthanensis, M. rhyncorhiza, M. tuberosa, $M$. umbellata, M. vitifolia, O. tansaensis and O. turpethum. Clade II comprises Xenostegia filiformis and $X$. tridentata. On the basis of dendrogram it is clear that both the Xenostegia species distantly differs with the remaining species of tribe Merremieae, which supports Austin and Staples (1980) segregation of the genus Xenostegia from Merremia. The present study is the first report depicting correlation between the members of the tribe Merremieae from India and also predicts the phylogenetic relationship within the members of the tribe.

\section{Acknowledgements}

Authors are thankful to the Head of the Botany department and Principal, The New College, Kolhapur for laboratory facilities. Thanks are due to the following persons and Institutes for permitting to consult their herbaria. The Director, Botanical Survey of India, Calcutta; Dr. P. G. Diwakar Ex-Deputy Director, BSI, Pune; Prof. S. R. Yadav Head of the Botany department, Shivaji University, Kolhapur; Dr. A. S. Dhabe, BAMU, Aurangabad and Dr. M. Y. Kamble, Scientist, BSI, Port Blair.

\section{References}

Almeida, M.R. and Almeida, S.M. 2001. Convolvulaceae In: Flora of Maharashtra. St. Xavier College, Mumbai, Vol. III B, pp. 303-350.

Austin, D.F. 1982. Operculina turpethum (Convolvulaceae) as a medicinal plant in Asia. Economic Botany, 36(3): 265-269.

Austin, D.F. and Staples, G.W. 1980. Xenostegia, a new genus of Convolvulaceae. Brittonia 32(4): 533-536.

Bhagat, R.B., Shimpale, V.B. and Deshmukh, R.B. 2009. Convolvulaceae In: Flora of Baramati. Bhagat Publications, Pune, pp. 212- 220.

Bhandari, M.M. 1995. Convolvulaceae In: Flora of the Indian Desert. MPS Reports, Jodhpur, pp. 216-237.

Biju, S.D. 1997. Taxonomic and morphologic studies in family Convolvulaceae of Southern Peninsular India. Unpublished $\mathrm{Ph}$. D. thesis, University of Calicut, India.

Chiapella, J. 2000. The Deschampsia cespitosa complex in central and Northern Europe. A morphological analysis. Bot. J. Linn. Soc. 134: 495-512.

Chopra, R.N., Nayar, S.L. and Chopra, I.C. 1995. Glossary of Indian Medicinal Plants. Council of Scientific and Industrial Research, New Delhi, p. 330.

Cooke, T. 1958 (Repr. ed.). Convolvulaceae In: The Flora of the Presidency of Bombay, Vol. 2. Botanical Survey of India, Calcutta, pp. 290-331.

Gamble, J.S. 1986. Convolvulaceae In: Flora of the Presidency of Madras. Bishen Singh Mahendra Pal Singh, Dehradun, India, pp. 901-930.

Gomez-Campo, C., Herranz-Sanz, J.M. and Montero-Riquelme, F. 2001. The genus Coincya Rouy (Cruciferae) in South-Central Spain revisited: A morphometric analysis of population structure. Bot. J. Linn. Soc. 135: 125-135.

Henderson, F.M. 2006. Morphology and anatomy of palm seedlings. Bot. Rev. 72: 273-329.

Hooker, J.D. 1885. Flora of British India, Vol. 4. L. Reeve \& Co. Ltd., London, pp. 179-228.

Johari, S.C. 1983. Genus Ipomoea L. in India, Ph. D. thesis (Unpublished). University of Rajasthan, Jaipur, India. 
Kamalutheen, M., Gopalakrishnan, S. and Syed Ismail, T. 2009. Anti-inflammatory and anti-arthritic activities of Merremia tridentata (L.) Hall.f. E- Journal of Chemistry 4: 943-948.

Kovach, W.L. 1999. MVSP-Multivariate statistical package for windows, version 3.1, Pentraeth Wales, UK. Kovach computing services.

Mabberley, D.J. 2008. Mabberly's Plant Book - a portable dictionary of plants, their classification and uses (Third Edition). Cambridge University Press, Cambridge, UK, pp. 1-1021.

Rahman, M.O., Rahman, M.Z. and Begum, A. 2013. Numerical taxonomy of the genus Senna Mill. from Bangladesh. Bangladesh J. Plant Taxon. 20(1): 77-83.

Sahu, P.K. and Gupta, S. 2014. Medicinal plants of Morning glory: Convolvulaceae Juss. of Central India (Madhya Pradesh and Chhattishgarh). Biolife 2(2): 463-469.

Singh, N.P., Lakshminarasimhan, P., Karthikeyan, S. and Prasanna, P.V. (Eds). 2001. Convolvulaceae In: Flora of Maharashtra State 2: 454 - 473. Botanical Survey of India, Calcutta.

Sneath, P.H.A. and Sokal, R.R. 1973. Numerical Taxonomy: The Principles and Practice of Numerical Classification ( $2^{\text {nd }}$ Edition), San Francisco: Freeman, pp. 1-573.

Soladoye, M.O., Sonibare, M.A. and Chukwuma, E.C. 2010. Morphometric study of the genus Indigofera Linn. (Leguminosae-Papilionoideae) in South-Western Nigeria. Int. J. Bot. 6(3): 343-350.

Sonibare, M.A., Jayeola, A.A. and Egunyomi, A. 2004. A morphometric analysis of the genus Ficus Linn. (Moraceae). Afr. J. Biotechnol. 3: 229-235.

(Manuscript received on 9 March 2014; revised on 4 November 2014) 